Atmos. Chem. Phys., 13, 9337-9350, 2013

www.atmos-chem-phys.net/13/9337/2013/

doi:10.5194/acp-13-9337-2013

(c) Author(s) 2013. CC Attribution 3.0 License.

\title{
Relating aerosol absorption due to soot, organic carbon, and dust to emission sources determined from in-situ chemical measurements
}

\author{
A. Cazorla ${ }^{1, *}$, R. Bahadur ${ }^{2}$, K. J. Suski ${ }^{1}$, J. F. Cahill ${ }^{1}$, D. Chand ${ }^{3}$, B. Schmid ${ }^{3}$, V. Ramanathan ${ }^{2}$, and K. A. Prather ${ }^{1,2}$ \\ ${ }^{1}$ Department of Chemistry and Biochemistry, University of California San Diego, La Jolla, California, USA \\ ${ }^{2}$ Scripps Institution of Oceanography, University of California San Diego, La Jolla, California, USA \\ ${ }^{3}$ Atmospheric Science and Global Change Division, Pacific Northwest National Laboratory, Richland, Washington, USA \\ *now at: Departamento de Física Aplicada, Universidad de Granada, Granada, Spain
}

Correspondence to: K. A. Prather (kprather@ucsd.edu)

Received: 15 December 2012 - Published in Atmos. Chem. Phys. Discuss.: 6 February 2013

Revised: 24 July 2013 - Accepted: 9 August 2013 - Published: 17 September 2013

Abstract. Estimating the aerosol contribution to the global or regional radiative forcing can take advantage of the relationship between the spectral aerosol optical properties and the size and chemical composition of aerosol. Long term global optical measurements from observational networks or satellites can be used in such studies. Using in-situ chemical mixing state measurements can help us to constrain the limitations of such estimates.

In this study, the Absorption Ångström Exponent (AAE) and the Scattering Ångström Exponent (SAE) derived from 10 operational AERONET sites in California are combined for deducing chemical speciation based on wavelength dependence of the optical properties. In addition, in-situ optical properties and single particle chemical composition measured during three aircraft field campaigns in California between 2010 and 2011 are combined in order to validate the methodology used for the estimates of aerosol chemistry using spectral optical properties.

Results from this study indicate a dominance of mixed types in the classification leading to an underestimation of the primary sources, however secondary sources are better classified. The distinction between carbonaceous aerosols from fossil fuel and biomass burning origins is not clear, since their optical properties are similar. On the other hand, knowledge of the aerosol sources in California from chemical studies help to identify other misclassification such as the dust contribution.

\section{Introduction}

Atmospheric aerosol particles are one of the most variable components of the Earth's atmosphere, and affect the Earth's radiative balance and climate directly by absorbing and scattering solar radiation (Haywood and Shine, 1995; Forster et al., 2007), and indirectly by acting as cloud condensation nuclei, changing the microphysical properties of clouds (Kaufman et al., 2005; Forster et al., 2007).

Absorption of solar radiation due to aerosol particles is mainly caused by carbonaceous particles (elemental carbon, EC, and organic carbon, OC) and mineral dust. The absorbing fraction of carbonaceous aerosols has been estimated as the second largest contributor to global warming (Jacobson et al., 2000; Ramanathan and Carmichael, 2008). However, the absorbing properties are strongly dependent on the mixing state of the particles (Bond and Bergstrom, 2006; Schnaiter et al., 2005). Further, current model estimates of aerosol forcing ascribe solar absorption entirely to elemental carbon (EC), treating the organic fraction (OC) as scattering (Koch et al., 2007; Myhre et al., 2008) and therefore may be underestimating the aerosol warming potential. Though this is a reasonable assumption in regions dominated by fossil fuel combustion, not only does carbon from all emission sources contain both elemental and organic fractions (Chow et al., 2009), but non-soot OC, particularly that emitted from biomass burning processes has a significant absorbing component at short wavelengths that may be comparable to the EC absorption (Jacobson, 1999; Kirchstetter et al., 2004; Andreae and Gelencser, 2006; Hoffer et al., 2006; Magi et al., 
2009). A separation of the total aerosol absorption into different chemical species is therefore essential; both for constraining the large uncertainties in current aerosol forcing estimates (Forster et al., 2007) and for informing emissions based control policy. Detailed studies of the chemical composition and size distribution of aerosol particles, and how they relate to the optical properties is therefore essential to evaluate their impact on climate.

Russell et al. (2010) highlighted that many recent studies have shown the persistent connections between aerosol absorbing species and the wavelength dependence of absorption. Thus, numerous studies have classified absorbing aerosol types from optical properties measured on ground stations (Eck et al., 1999; Dubovik et al., 2002; Collaud Coen et al., 2004; Fialho et al., 2005; Meloni et al., 2006; Kalapureddy et al., 2009; Mielonen et al., 2009; Giles et al., 2011, 2012) and from satellites (Higurashi and Nakajima, 2002; Barnaba and Gobbi, 2004; Jeong and Li, 2005; Kaufman et al., 2005; Torres et al., 2005; Kaskaoutis et al., 2007; Kim et al., 2007; Yu et al., 2009). In this study, in-situ optical properties and single particle chemical composition measured during three aircraft field campaigns are combined in order to validate a methodology for the estimation of absorbing aerosol types using spectral optical properties. In addition, this approach is extended and applied to a long term remote sensing optical measurements database, i.e. AERONET (Holben et al., 1998), using data from California stations.

\section{Experimental data}

\subsection{Remote sensing measurements}

Most previous studies showing a connection between absorbing aerosol types and optical properties were based on remote-sensing measurements at locations with a strong dominant type, e.g. deserts, urban polluted areas, regions prone to wildfires, etc.

AERONET (Holben et al., 1998) is an optical groundbased aerosol monitoring network that provides globally distributed observations of aerosol spectral optical depths (AOD), and other properties derived by inversion such as aerosol size distributions and single scattering albedo (SSA). AERONET follows a protocol for the quality assured data (Level 2.0). AERONET Level 2.0 data are cloud screened and, only measurement with AOD at $440 \mathrm{~nm}$ greater than 0.4 are used, for which the uncertainty of the AOD is between 0.01 and 0.02 depending on the wavelength (Holben et al., 1998), and this uncertainty results in a variation of 0.03 to 0.04 in the Ångstrom exponent (Schuster et al., 2006) and of 0.03 to 0.07 in the SSA (Dubovik et al., 2002).

In this study, we used AERONET measurements from 33 stations around the world with a dominant absorbing species (Table 1). In addition, we used measurements from a total of ten operational AERONET stations in California. The sta-
Table 1. List of the AERONET stations around the world with dominant sources used for the creation of the Ångström matrix.

\begin{tabular}{lrrl}
\hline AERONET station & $\begin{array}{r}\text { Latitude } \\
\left({ }^{\circ}\right) \mathrm{N}\end{array}$ & $\begin{array}{r}\text { Longitude } \\
\left({ }^{\circ}\right) \mathrm{W}\end{array}$ & Main source \\
\hline Billerica & 42.53 & 71.27 & Fossil Fuel \\
CCNY & 40.82 & 73.95 & Fossil Fuel \\
Dayton & 39.77 & 84.11 & Fossil Fuel \\
Fresno & 36.78 & 119.77 & Fossil Fuel \\
GSFC & 38.99 & 76.84 & Fossil Fuel \\
Halifax & 44.64 & 63.59 & Fossil Fuel \\
Hamburg & 53.57 & -9.97 & Fossil Fuel \\
Hong Kong & 22.21 & -114.26 & Fossil Fuel \\
IFT Leipzig & 51.35 & -12.43 & Fossil Fuel \\
Mainz & 49.99 & -8.3 & Fossil Fuel \\
Maryland Sci. Cen. & 39.28 & 76.62 & Fossil Fuel \\
New Delhi & 28.63 & -77.17 & Fossil Fuel \\
Palaiseau & 48.7 & -2.21 & Fossil Fuel \\
Philadelphia & 40.04 & 75 & Fossil Fuel \\
Rome Tor Vergata & 41.84 & -12.65 & Fossil Fuel \\
Sandy Hook & 40.45 & 73.99 & Fossil Fuel \\
UCLA & 34.07 & 118.45 & Fossil Fuel \\
Abracos Hill & 10.76 & 62.35 & Biomass Burning \\
Alta Floresta & -9.87 & 56.1 & Biomass Burning \\
Belterra & -2.65 & 54.95 & Biomass Burning \\
Campo Grande & -20.45 & 54.62 & Biomass Burning \\
CELAP-BA & -34.57 & 58.5 & Biomass Burning \\
Cordoba CETT & -31.52 & 64.46 & Biomass Burning \\
CUIABA Miranda & -15.73 & 56.02 & Biomass Burning \\
Mongu & -15.25 & -23.15 & Biomass Burning \\
Petrolina SONDA & -9.38 & 40.5 & Biomass Burning \\
Rio Branco & -9.96 & 67.87 & Biomass Burning \\
Skukuza Aeroport & -24.97 & -31.59 & Biomass Burning \\
Eilat & 29.5 & -34.92 & Dust \\
Hamim & 22.97 & -54.3 & Dust \\
Solar Village & 24.91 & -46.39 & Dust \\
Tamanrasset INM & 22.79 & -5.53 & Dust \\
Tamanrasset TMP & 22.79 & -5.53 & Dust \\
\hline & & & \\
\hline
\end{tabular}

tions are divided by region, into Northern California for the stations with latitude above $36^{\circ} \mathrm{N}$ and Southern California for the stations below $36^{\circ} \mathrm{N}$. Southern California is characterized by densely populated cities, such as Los Angeles or San Diego where the main source is anthropogenic. On the other hand, Northern California is, in general, a less populated region, with the Central Valley characterized by an important agricultural activity. Data are also divided by seasons. Due to the limited availability of Level 2.0 AERONET data, seasons were grouped using winter and spring in one season and summer and autumn in another season. Table 2 presents the name, location, available period of time in years, and number of valid Level 2.0 measurements for the $10 \mathrm{Cal}-$ ifornia AERONET stations. The stations are also shown on the map in Fig. 1. 


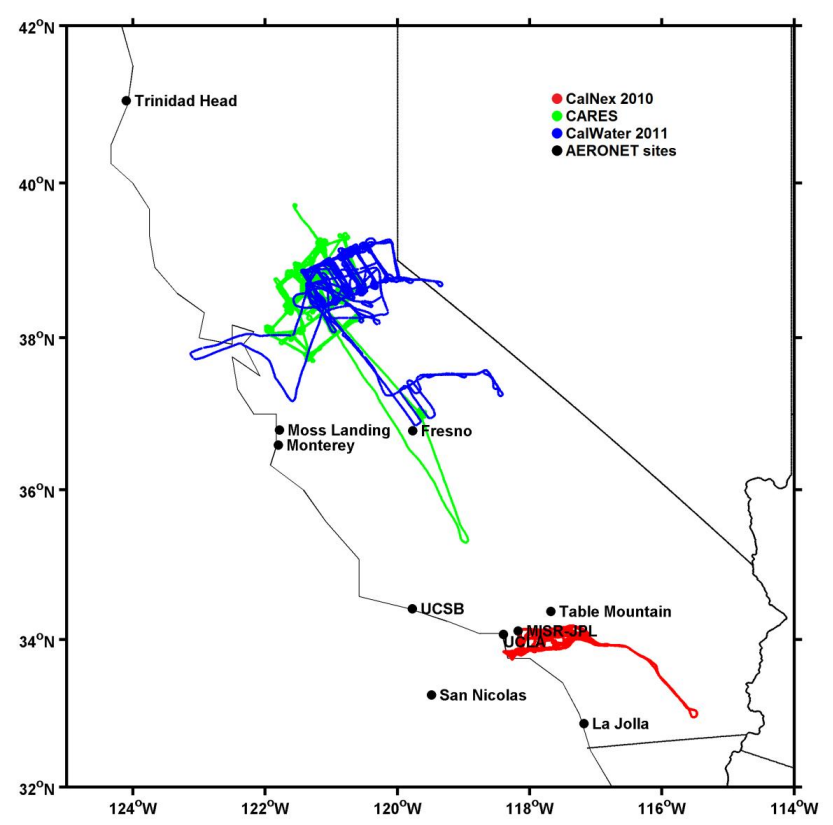

Fig. 1. Map of California with the flight paths of the aircraft campaigns and the location of the AERONET stations.

\subsection{In-situ aircraft measurements}

In-situ data were measured during three aircraft field campaigns performed in California. CalNex 2010 was a joint field study coordinated by the California Air Resources Board (CARB), the National Oceanic and Atmospheric Administration (NOAA) and the California Energy Commission (CEC), with a primary goal to study atmospheric processes over California and the eastern Pacific coastal region. Measurements used in this work were taken on the Center for Interdisciplinary Remotely-Piloted Aircraft Studies (CIRPAS) Twin Otter, flying mainly in the Los Angeles basin during May 2010. CARES (Carbonaceous Aerosols and Radiative Effects Study), was a field study designed to increase scientific knowledge about evolution of black carbon and secondary organic aerosols from both urban/manmade and biogenic sources. Data used from this campaign were measured onboard the DOE Gulfstream-1 (G-1), based in Sacramento during June 2010. The CalWater 2011 field campaign was designed to better assess the effects of aerosols on precipitation in the Sierra Nevada during the winter season. Data used from this campaign were collected onboard the DOE G1, based in Sacramento, between February and March 2011. Figure 1 shows the flight paths for the three campaigns.

The different aircrafts contained instrumentation for the retrieval of the optical properties of aerosols, i.e. absorption and scattering coefficients, and for the measurement of the chemical composition of aerosol particles. The Absorption coefficient, $\sigma_{\mathrm{a}}$ was derived using a Particle Soot Absorption Photometer (PSAP) at 462, 523 and $648 \mathrm{~nm}$ sampling from an iso-kinetic inlet. The Scattering coefficient, $\sigma_{\mathrm{s}}$, was measured using a nephelometer at 450,550 and $700 \mathrm{~nm}$ during CARES and CalWater, also sampling from an iso-kinetic inlet, and derived from a Passive Cavity Aerosol Spectrometer Probe (PCASP) size distribution, in the range of 0.1 to $3 \mu \mathrm{m}$, applying Mie theory (using a refractive index of 1.5) during CalNex. PSAP data were corrected for scattering aerosol and spot size based on Bond et al. (1999) and Ogren (2010) using the nephelometer data for CARES and CalWater data, and the calculated scattering for CalNex. The uncertainty associated to the $\sigma_{\mathrm{a}}$ is about $20 \%$ (Bond et al., 1999). Nephelometer data were corrected based on Anderson and Ogren (1998). The uncertainty associated to $\sigma_{\mathrm{s}}$ is about $5 \%$.

As discussed by Schmid et al. (2006), the Twin Otter samples aerosol from an iso-kinetic inlet whose passing efficiency was tested in airborne and wind tunnel experiments by Hegg et al. (2005). They found no appreciable loss in efficiency for particles smaller than $3.5 \mu \mathrm{m}$ diameter at the Twin Otter sampling velocity of $50 \mathrm{~m} \mathrm{~s}^{-1}$. For larger particles, the efficiency decreases rapidly but levels off at an efficiency of slightly better than 0.6 for particles $5.5-9 \mu \mathrm{m}$ (the latter being the upper diameter of their characterization). The G-1 iso-kinet inlet used in CARES and CalWater has not yet undergone the same testing. Manufacturer specifications call for passing efficiency near unity dropping to $50 \%$ at $5 \mu \mathrm{m}$ diameter at the G-1 research speed of $100 \mathrm{~m} \mathrm{~s}^{-1}$. This claim has been substantiated with comparisons with ground-based nephelometers during fly-bys in CARES (Zaveri et al., 2012).

Measurements of the chemical composition of individual particles during the three aircraft campaigns were performed using the aircraft aerosol time-of-flight mass spectrometer (A-ATOFMS) (Pratt et al., 2009). The A-ATOFMS measures, in real time, the size and chemical composition of individual particles ranging in size from 100 to $2500 \mathrm{~nm}$ during CalWater and from 80 to $1000 \mathrm{~nm}$ during CalNex and CARES. Following a ${ }^{210} \mathrm{Po}$ neutralizer and pressure controlled inlet (Bahreini et al., 2003), particles are focused in an aerodynamic lens system. The particles are optically detected by two $532 \mathrm{~nm}$ lasers spaced $6.0 \mathrm{~cm}$ apart, providing particle velocity and, ultimately, vacuum aerodynamic diameter $\left(d_{\mathrm{va}}\right)$. Finally, species are desorbed and ionized using $266 \mathrm{~nm}$ radiation from a Q-switched Nd:YAG laser operating at $\sim 0.4-1.0 \mathrm{~mJ}$. Positive and negative ion mass spectra resulting from individual particles are measured in a dualpolarity time-of-flight mass spectrometer.

\section{Methodology}

Russell et al. (2010) used the Absorption Ångström Exponent (AAE) as an indicator of aerosol chemical composition and they showed a clustering by absorbing aerosol types on an AAE vs. EAE (Extinction Ångström Exponent) scatter plot. In this study, we apply a similar methodology, based on a previous study by Bahadur et al. (2012), dividing the 
AAE vs. SAE (Scattering Ångström Exponent) space, the Ångström matrix, in different regions that are associated with different absorbing aerosol types.

\subsection{Remote sensing measurements}

In order to calculate the AAE and SAE, the Single Scattering Albedo (SSA) derived by inversion in AERONET is used to calculate the Absorption and Scattering components of the aerosol optical depth (AOD). This way, AAOD $=$ AOD $\cdot(1-$ SSA) and SAOD = AOD $\cdot$ SSA are calculated. Then, AAE and SAE are calculated using Eq. (1) and Eq. (2) respectively:

$\operatorname{AAE}=-\frac{\log \left(\operatorname{AAOD}\left(\lambda_{1}\right) / \operatorname{AAOD}\left(\lambda_{2}\right)\right)}{\log \left(\lambda_{1} / \lambda_{2}\right)}$

$\operatorname{SAE}=-\frac{\log \left(\operatorname{SAOD}\left(\lambda_{1}\right) / \operatorname{SAOD}\left(\lambda_{2}\right)\right)}{\log \left(\lambda_{1} / \lambda_{2}\right)}$

where the wavelengths, $\lambda_{1}$ and $\lambda_{2}$, are 440 and $675 \mathrm{~nm}$ respectively.

The spectral dependence of the absorption coefficient, AAE in Eq. (1), can be related to the dominant absorbing aerosol type for a mixture of aerosols. Black carbon typically follows a $\lambda^{-1}$ spectral dependence, yielding an AAE of 1 (Bergstrom et al., 2002), while organic carbon in biomass smoke aerosols and mineral dust contribute to light absorption in the ultraviolet and blue spectral regions yielding an AAE greater than 1 (Kirchstetter et al., 2004) with a magnitude depending on the range of wavelengths used for its calculation. Gyawali et al. (2009) and Lack and Cappa (2010) found that values of AAE $>1$ are also possible on particles with $\mathrm{BC}$ cores and a non-absorbing coating. On the other hand, the spectral dependence of the scattering coefficient, the SAE as shown in Eq. (2), depends primarily on the dominant size mode for a mixture of aerosols, ranging from 4 to 0 where larger numbers associate with small particles, i.e. fine mode, and smaller numbers suggest the dominance of large particles, i.e. coarse mode (Bergstrom et al., 2007).

Thus, in a very intuitive way, the AAE vs. SAE space partitions into regions that correlate to combinations of a dominance of fine and coarse modes, and a dominance of particles that follow the $\lambda^{-1}$ trend for absorption, and those with absorption enhancement on the shorter wavelengths. The principal advantage of this dual size-chemistry related partitioning is that in the ideal case it separates the three aerosol absorbing species - EC, OC, and mineral dust. First, measurements representing dust separate along the SAE axis, as dust is primarily found in the coarse mode as compared to carbonaceous aerosols that are primarily in the fine and ultrafine mode close to emission sources. Second, EC is an efficient absorber at all wavelengths compared to OC which absorbs strongly only at short wavelengths, separating these species along the AAE axis. In addition to these ideal cases we can relate the remainder of the phase space to aerosols with predicted combinations of SAE (representing size) and AAE (representing chemistry), and their mixtures. This partition is based on a simplified division published by Bahadur et al. (2012). In the supplemental material of Bahadur et al. (2012), a threshold value of $\mathrm{AAE}=1.5$ was found to demarcate the dust dominated region fairly well, containing $72 \%$ of all measurements in dust-dominated regions, but only $17 \%$ of measurements in fossil fuel dominated regions. Therefore, the condition of AAE > 1.5 has been retained to delineate the aerosols that have an enhanced absorption at shorter wavelengths (i.e. dust and OC) with smaller values of AAE considered to have an influence of EC leading to more complex mixtures. Similarly, SAE of 1.5 was found to reasonably delineate the fine mode aerosols (EC and OC) with smaller values of SAE considered to have an influence of larger particles (such as dust or other non-absorbing species), again leading into the mixture containing regions of the phase space. In this new partition, the inclusion of mixtures requires the addition of new phase boundaries. Thus, the phase boundaries for large particles and "EC dominated" particles were set to 1.0.

Figure 2 illustrates the division of the Angström matrix with labels that represent the three absorbing aerosol species and their mixtures. The lower-left quadrant has been labeled as "coated large particles" indicating that it contains a species with $\mathrm{AAE}<1$ but larger in size. Lack and Cappa (2010) showed that black carbon particles with a sulfate coating might present those optical properties, and polluted dust with strong absorbers might also present the same spectral response. Figure 2 also shows data from the 33 AERONET stations color coded by dominant type and Table 1 lists the stations and its location and dominant aerosol species.

Measurements from dust dominant stations (orange squares) fall mainly into the dust dominant area (upperleft quadrant), however some measurements fall into the phase space representing polluted dust, mixed aerosols, or the coarse coated type. On the other hand, there is a larger overlap between absorbing particles from fossil fuel (cyan triangles) and biomass burning sources (red circles) since all combustion produces both EC and OC, and there are no pure EC or OC present in field measurements. However, the fossil fuel category presents more variability in size than the biomass burning category due to the origin of the measurements. Whereas biomass burning dominant stations are mainly areas prone to wildfires, the stations marked as fossil fuel correspond to urban areas that are expected to contain a large amount of primary carbonaceous aerosols, but likely also contain larger aerosol particles (either lofted dust, or non-absorbing aerosols), and likely also contain aged secondary aerosols due to high $\mathrm{NO}_{\mathrm{x}}$ and ozone conditions. 


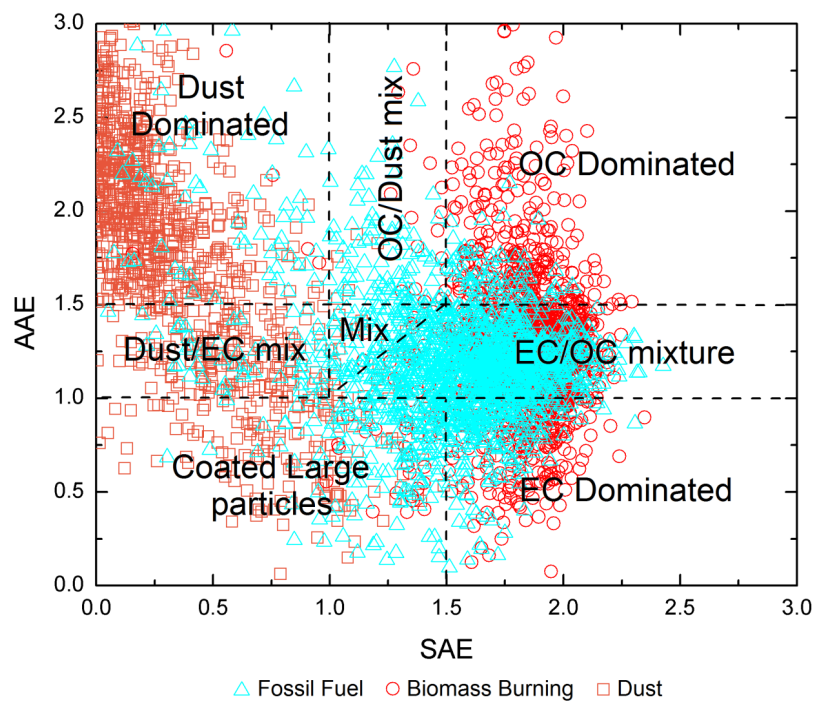

Fig. 2. Division of the Absorption Ångström Exponent vs. Scattering Ångström Exponent space, the Ångström matrix, overlapped with the AERONET measurements from stations with a dominant sources (fossil fuel in cyan triangles, biomass burning in red circles or dust in orange squares).

\subsection{In-situ aircraft measurements}

Using the in-situ optical properties and chemical composition measured during the three aircraft field campaigns, we can establish a link between the optical properties, in this case the AAE and the SAE, and the measured chemical composition of the aerosol particles.

AAE and SAE were calculated applying Eqs. (1) and (2) respectively using $\sigma_{\mathrm{a}}$ instead of the column integrate value (AAOD) and $\sigma_{\mathrm{s}}$ instead of the SAOD. Wavelengths used as $\lambda_{1}$ and $\lambda_{2}$ were 462 and $648 \mathrm{~nm}$ for the PSAP and 450 and 700 for the nephelometer, since those are closer to the AERONET wavelength used in Sect. 3.1.

For the chemical composition of the particles from the AATOFMS, spectra from individual particles, i.e. their chemical signature, are grouped into chemically similar clusters using the ART-2-a algorithm (Song et al., 1999). The initial clusters are then manually grouped in a small set of clusters based on the identification of the mass spectral peaks that correspond to the most probable ions for a given massto-charge ratio $(\mathrm{m} / \mathrm{z})$ based on previous lab and field studies. These clusters are then classified into different absorbing particle types: primary fossil fuel, secondary fossil fuel, primary biomass burning, secondary biomass burning and dust, excluding other non-absorbing particle types. Figure 3 shows a representative mass spectrum for each aerosol type where the mass-to-charge ratio $(\mathrm{m} / \mathrm{z})$ is on the $x$ axis, and the intensity of the ion peaks is on the $y$ axis (in arbitrary units).

Briefly, primary fossil fuel particles are characterized by the presence of carbon cluster ion peaks: $C_{n}^{+}$and $\mathrm{C}_{n}^{-}$, repre- sentative of the elemental carbon (EC), and spectra that also contain weak m/z $27\left(\mathrm{C}_{2} \mathrm{H}_{3}^{+}\right), 37\left(\mathrm{C}_{3} \mathrm{H}^{+}\right)$and $39\left(\mathrm{C}_{3} \mathrm{H}_{3}^{+}\right)$. Secondary fossil fuel particles contain $m / z 27\left(\mathrm{C}_{2} \mathrm{H}_{3}^{+} / \mathrm{CHN}^{+}\right)$, $37\left(\mathrm{C}_{3} \mathrm{H}^{+}\right), 39\left(\mathrm{C}_{3} \mathrm{H}_{3}^{+}\right)$and $43\left(\mathrm{C}_{2} \mathrm{H}_{3} \mathrm{O}^{+}\right)$in the positive spectra and mainly nitrate and sulfate ion peaks in the negative ion mass spectra: $m / z-62\left(\mathrm{NO}_{3}^{-}\right)$and $-97\left(\mathrm{HSO}_{4}^{-}\right)$respectively (Silva and Prather, 2000; Spencer and Prather, 2006; Moffet and Prather, 2009). Biomass burning particles are characterized by an intense potassium peak $\mathrm{m} / \mathrm{z}$ $39\left(\mathrm{~K}^{+}\right)$with less intense carbonaceous markers (e.g. $\mathrm{m} / \mathrm{z}$ 12(C+), 27 $\left(\mathrm{C}_{2} \mathrm{H}_{3}^{+}\right), 36\left(\mathrm{C}_{3}^{+}\right), 37\left(\mathrm{C}_{3} \mathrm{H}^{+}\right)$(Silva et al., 1999; Hudson et al., 2004). The difference between primary and secondary biomass burning is established by looking at the negative spectra that presents carbon clusters in the case of primary biomass burning or mainly nitrate/sulfates in the case of secondary biomass burning. Finally, dust is characterized by inorganic ion peaks e.g. $m / z 27\left(\mathrm{Al}^{+}\right), 39\left(\mathrm{~K}^{+}\right)$, and/or $40\left(\mathrm{Ca}^{+}\right)$, and the presence of silicates: $-60\left(\mathrm{SiO}_{2}^{-}\right)$ and $-76\left(\mathrm{SiO}_{3}^{-}\right)$(Silva et al., 2000).

In order to validate the Ångström matrix, we matched the spectral optical properties and the aerosol absorbing types measured by the A-ATOFMS during the flights. For each flight, we calculated the $5 \mathrm{~min}$ average of the AAE and SAE. On the other hand, for the same 5 min periods, we calculated the fraction of the different aerosol absorbing types detected with the A-ATOFMS. We only considered periods with a dominant aerosol absorbing type, i.e. $75 \%$ of the particles detected by the A-ATOFMS are from one type. Thus, we screen the data using the $5 \mathrm{~min}$ average values that correspond with a dominant aerosol absorbing type detected by the A-ATOFMS. This way we have, on one hand the spectral optical properties (AAE and SAE) and we can obtain an estimation of the type of absorber using the Ångström matrix and, on the other hand, the actual aerosol chemical composition determined by the A-ATOFMS that correspond to those optical properties.

\section{Results}

To gain a better understanding on how the optical properties of aerosols relate to chemical composition, we use aerosol data from California as an initial test case, where the Ångström matrix can be compared to a large wealth of field data. Applying the Ångström matrix to all the available Level 2.0 AERONET data, we obtain an estimate for the percentage of absorbers in different regions of California by means of optical properties. Figure 4 shows the fraction for the different regions and seasons in pie charts. Panel (a) shows the fraction for Northern California during winter/spring; panel (b) shows the fraction for northern California during summer/autumn, panels (c) and (d) shows the fraction for southern California during winter/spring and summer/autumn, respectively. Due to the number of retrievals for each site (Table 2), the northern California is strongly biases by Fresno 

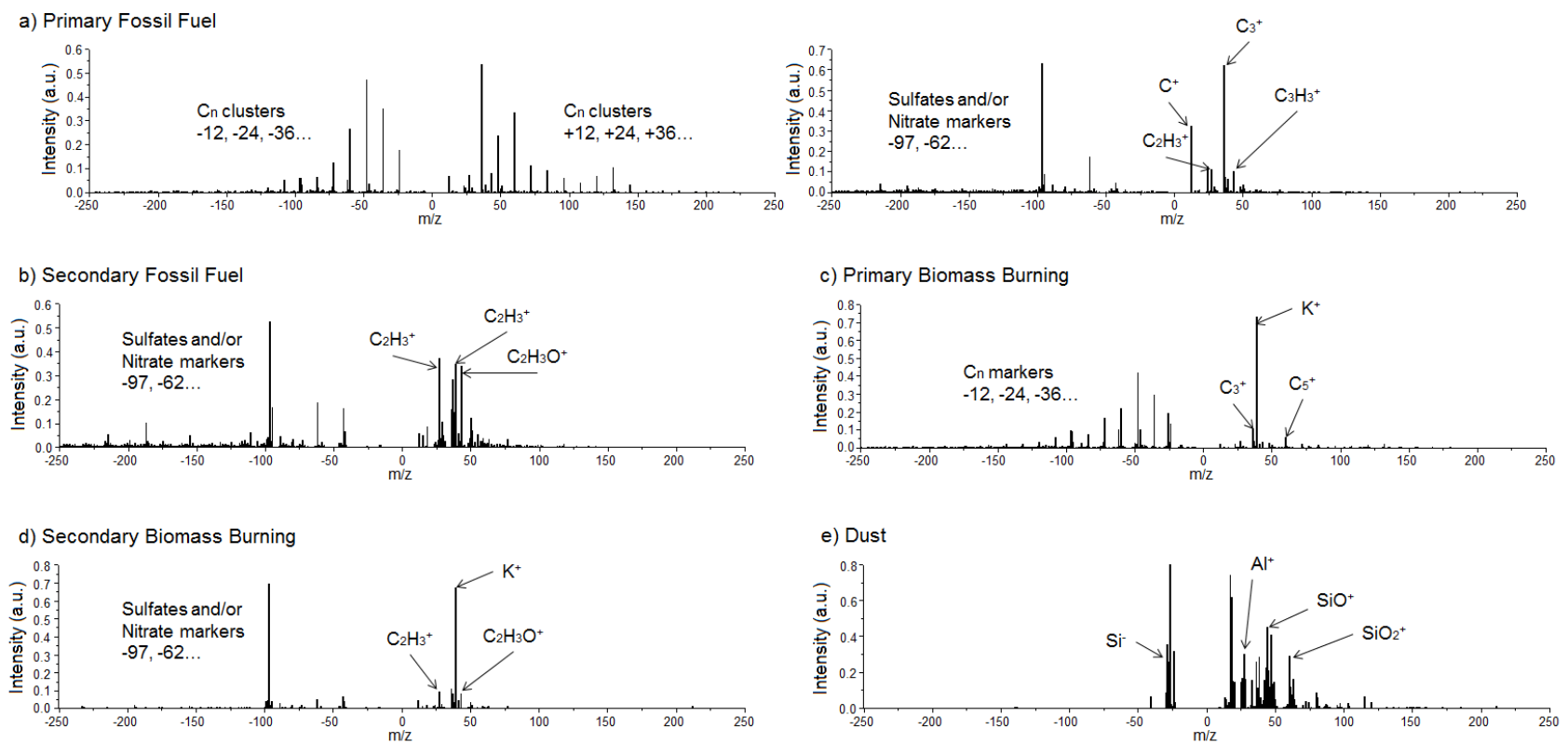

Fig. 3. Representative A-ATOFMS spectra for different aerosol sources (a) primary fossil fuel, (b) secondary fossil fuel, (c) primary biomass burning, (d) secondary biomass burning, and (e) dust.

Table 2. Location and data availability of the AERONET stations in California.

\begin{tabular}{lllll}
\hline AERONET station & Latitude $\left(^{\circ}\right) \mathrm{N}$ & Longitude $\left(^{\circ}\right) \mathrm{W}$ & Data Availability & $\begin{array}{l}\text { Data points with } \\
\text { SSA retrieval }\end{array}$ \\
\hline Fresno & 36.782 & 119.773 & $2002-2011$ & 208 \\
La Jolla & 32.870 & 117.250 & $1994-2011$ & 15 \\
MISR-JPL & 34.119 & 118.174 & $1996-2009$ & 28 \\
Monterey & 36.593 & 121.855 & $1998-2011$ & 6 \\
Moss Landing & 36.793 & 121.788 & $2004-2006$ & 2 \\
San Nicolas & 33.257 & 119.487 & $1997-2007$ & 14 \\
Table Mountain & 34.380 & 117.680 & $1998-2011$ & 3 \\
Trinidad Head & 41.054 & 124.151 & $2005-2011$ & 13 \\
UCLA & 34.070 & 118.450 & $2000-2009$ & 55 \\
UCSB & 34.415 & 119.845 & $1994-2011$ & 10 \\
\hline
\end{tabular}

site, and southern California by the Los Angeles basin measurements. Both seasons in northern California show similar fraction of aerosol absorbing types and they are dominated by a mixture of EC and OC aerosol that contribute over $40 \%$ of all measurements. The difference lies in the coated large particles and mix types. For southern California, the summer/autumn season is dominated by a mixture, or EC and OC aerosol (almost $40 \%$ ) as well as OC and OC mixed with dust type. The winter/spring season is dominated by dust (over $45 \%$ ) and coated large particles (almost $30 \%$ ).

On the other hand, a summary of the overall aerosol absorbing types detected with the A-ATOFMS during the three campaigns is shown in Fig. 5. Each pie chart represents the number fraction of absorbing types detected during CalNex on the left panel, CARES in the middle, and CalWater on the right panel calculated using all the available particles detected during the flights. Also each campaign, because of the location and dates, can be associated with a region and season. CalNex corresponds with southern California during the summer, or concretely with the Los Angeles basin area, CARES with northern California also during the summer, and CalWater with northern California during the winter. We need to take into account that we are using different instruments and methodologies. On one hand, AERONET data represent a long-term dataset and Fig. 4 represents the fraction of occurrences falling into one or another region in the Ångström matrix and, on the other hand, A-ATOFMS data shown in Fig. 5 represents the fraction of particles detected at a specific location and time. Furthermore, for northern $\mathrm{Cal}-$ ifornia, the AERONET retrievals are biased by the Fresno 

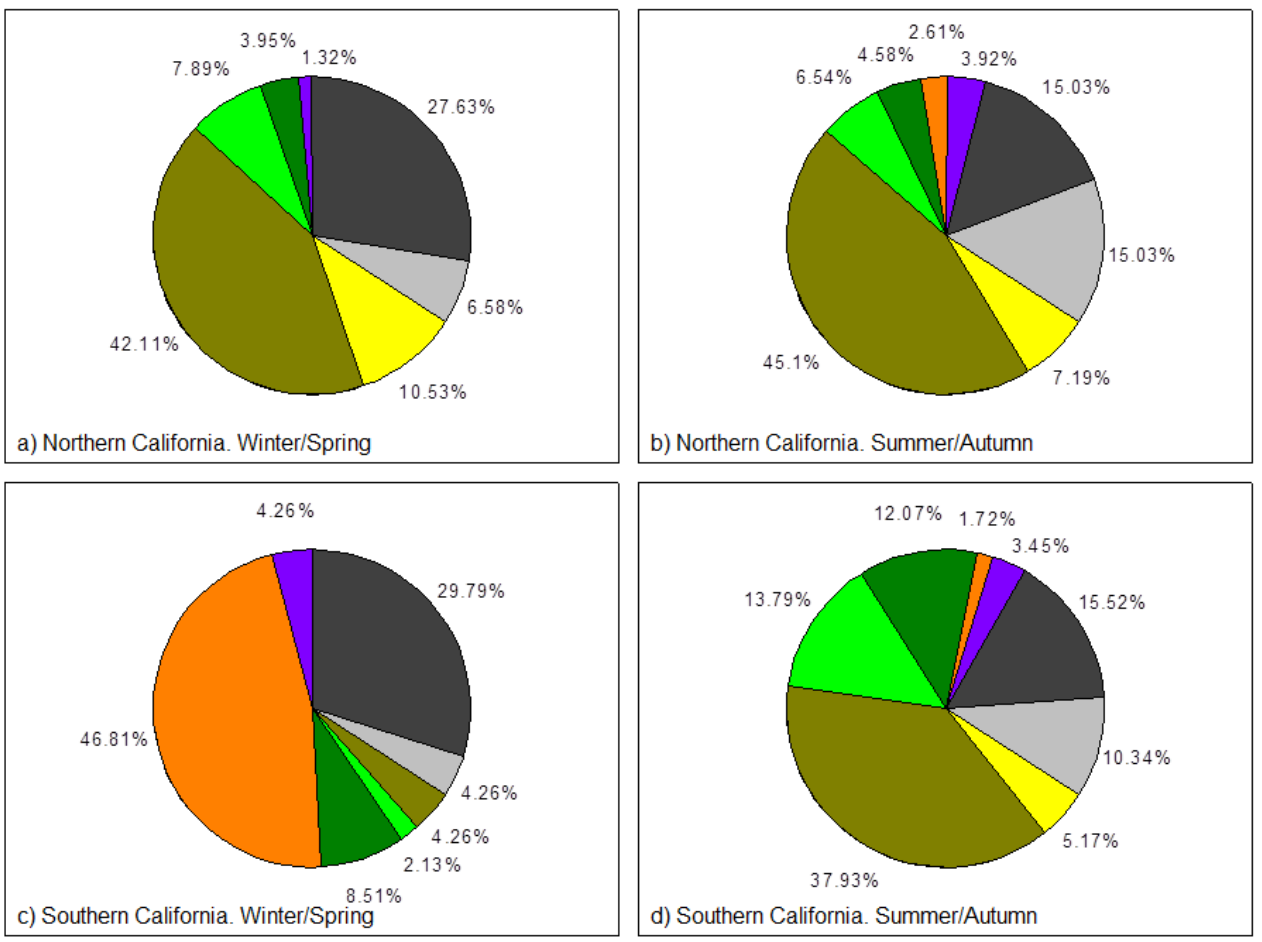

$\mathrm{EC}=\mathrm{EC} / \mathrm{OC}=\mathrm{OC}$

OC/Dust

d) Southern California. SummeriA

Fig. 4. Estimated number fraction of the different aerosol absorbing types by the Angstrom matrix using aerosol properties from AERONET stations in California separated by region and season: (a) Northern California - winter/spring, (b) Northern California - summer/autumn, (c) Southern California - winter/spring, and (d) Southern California - summer/autumn.

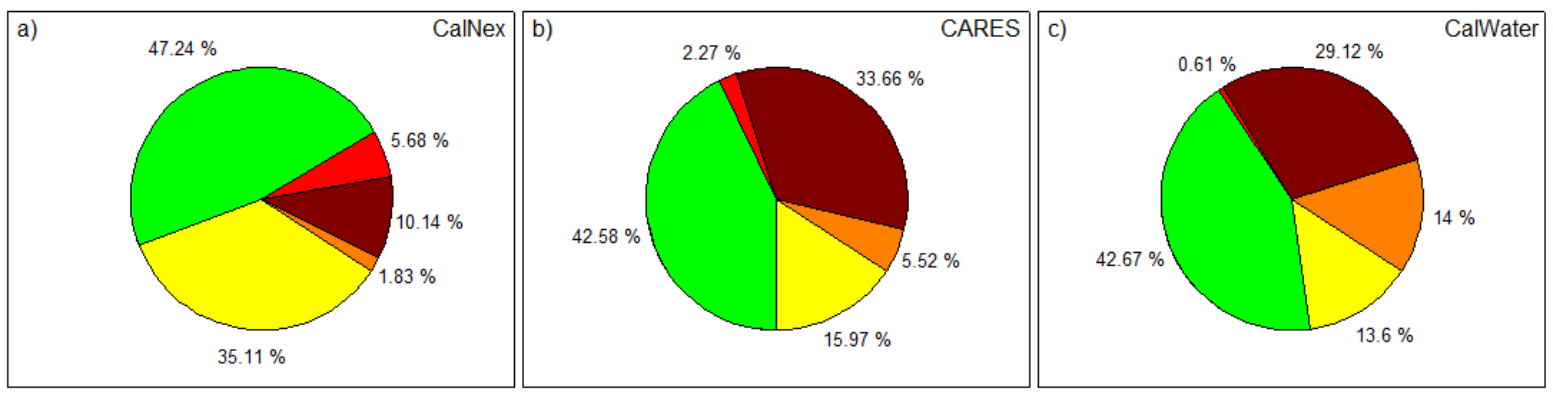

Primary Fossil Fuel $\quad$ Secondary Fossil Fuel $\quad$ Primary Biomass Burning Secondary Biomass Burning

Fig. 5. Overall aerosol sources detected with the A-ATOFMS in the three aircraft campaigns: (a) CalNex, (b) CARES, and (c) CalWater.

measurements and the aircraft measurements are mainly on the Sacramento area. Both seasons in northern California present similar aerosol absorbing type fraction with dominance of secondary fossil fuel aerosol and biomass burning particles. Also, more dust is detected during the winter. In southern California, the primary fossil fuel particles $(35 \%)$ and secondary fossil fuel $(47 \%)$ dominate in the summer.

In the validation process the AAE and SAE values, calculated from the in-situ aircraft data, that match the dominant aerosol type criteria presented in Sect. 3.2 are represented, in Fig. 6, on an AAE vs. SAE scatter plot with color representing the dominant aerosol type determined by the AATOFMS. Panels (a), (b) and (c) correspond to each different field campaign (CalNex, CARES and CalWater respectively). Since the AAE is related to the chemical composition of aerosol, panel (d) in Fig. 6 shows a frequency histogram of the AAE associated to the aerosol types detected by A-ATOFMS showing that primary fossil fuel particles 

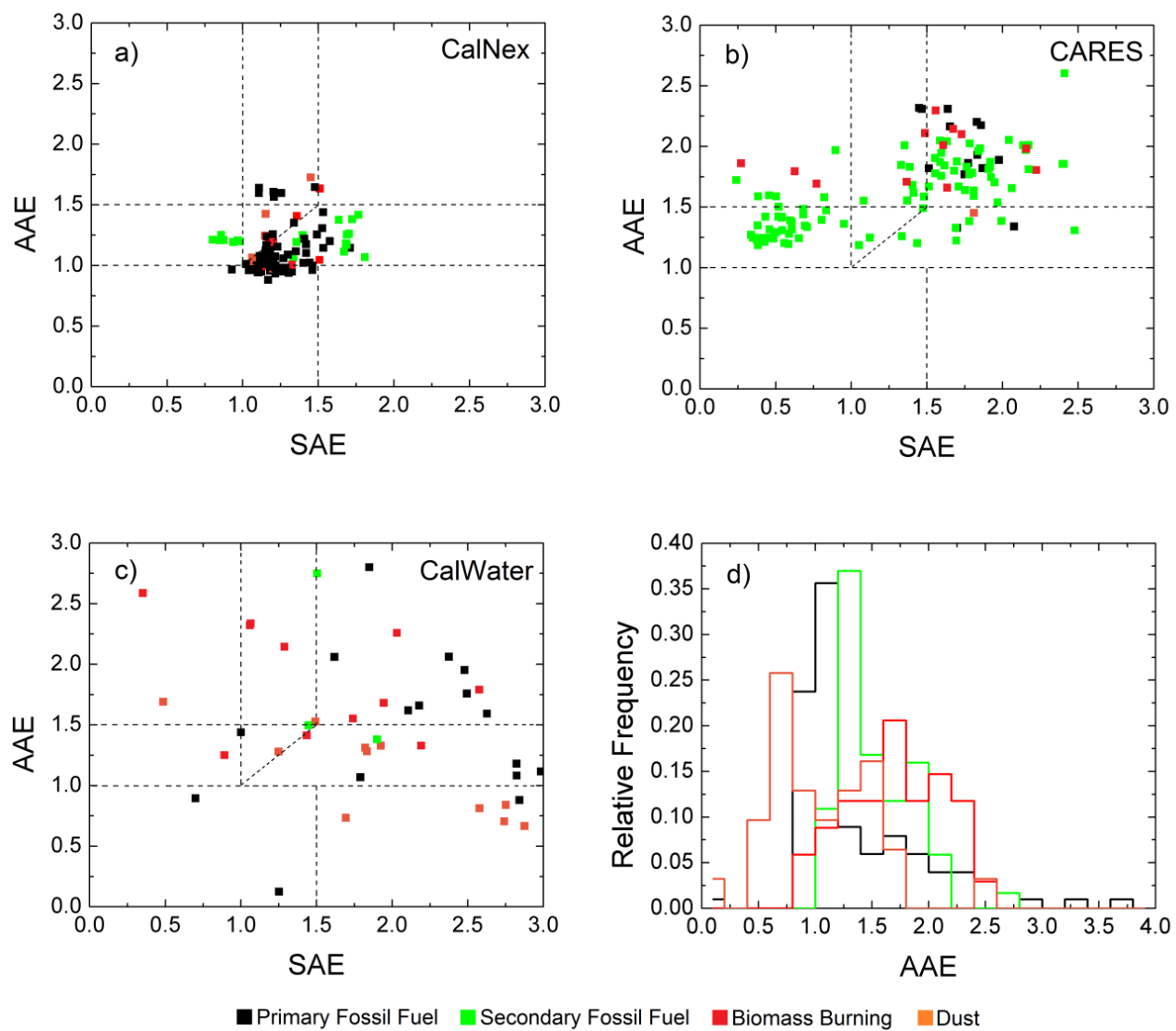

Fig. 6. Absorption Ångström Exponent vs. Scattering Ångström Exponent scatter plot of in-situ aircraft measurements for (a) CalNex, (b) CARES, and (c) CalWater where the color code represents the dominant aerosol source detected with the A-ATOFMS for each measurement. Panel (d) is a frequency histogram of the Absorption Ångström Exponent for each aerosol source.

have a mean value of $\mathrm{AAE}=1.1 \pm 0.6$, which is close to the expected 1 for black carbon (Bergstrom et al., 2002). Secondary fossil fuel particles can be associated with an AAE = $1.5 \pm 0.3$ in agreement with what was found by Gyawali et al. (2009) and Lack and Cappa (2010) for BC cores with nonabsorbing coatings, and biomass burning to $\mathrm{AAE}=1.8 \pm 0.4$ (Kirchstetter et al., 2004). AAE is smaller on average during CalNex than during CARES, consistent with the type of dominant aerosol detected, mainly primary fossil fuel during CalNex, i.e. elemental carbon, in contrast with the secondary fossil fuel particles that dominate during CARES. The number of samples from the CalWater campaign is small, as the flights focused on clouds and not many data samples were acquired from cloud free air. SAE shows less variability during CalNex than during CARES, but we need to take into account that the scattering coefficient measurements were taken differently for those campaigns and the range of particle sizes is different. Also the data filtering might be introducing a bias, since we are using data corresponding to periods with a dominant aerosol source.

Finally, we apply the Ångström matrix to the in-situ optical properties, obtaining an estimate of the aerosol chemical composition using optical properties that can be compared with the actual aerosol chemical composition determined by the A-ATOFMS. Table 3 shows a contingency table where the rows are the chemical composition detected with the AATOFMS and columns are the different estimated aerosol types from the Ångström matrix. Values presented are percentages of measurements classified in one type or another and they sum 100 across rows. Primary fossil fuel particles, i.e. elemental carbon, were classified mainly as organic carbon or a mixture of organic carbon and elemental carbon or dust. Secondary fossil fuel particles, i.e. secondary organic aerosols, fall mainly into the dust/EC mix (almost $40 \%$ ) indicating that those were particles with absorption properties similar to organic carbon, but larger in size, probably due to non-absorbing coating on the carbonaceous core. On the other hand, primary biomass burning sources were classified as organic carbon, organic mixed with dust, or well mix types. Secondary biomass burning sources are classified in almost $60 \%$ into the organic carbon or organic carbon mixed with dust categories. Finally, dust sources were only significant during CalWater. However, the Ångström matrix does 
Table 3. Contingency matrix constructed from the aircraft measurements representing the percentage of aerosol sources from the A-ATOMFS classified into the different Ångström matrix classes.

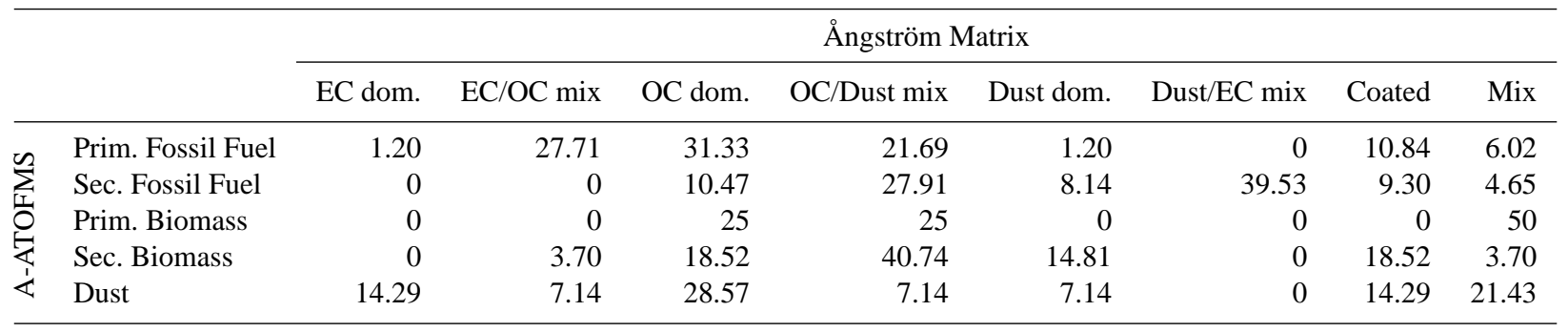

not classify them correctly as dust dominated type mainly because of the small amount of dust measurements.

\section{Discussion}

The estimates of aerosol types applying the Ångström matrix to the California AERONET stations (Fig. 4) show similar aerosol contributions in both seasons in northern California. Over $40 \%$ of the contribution is due to a mixture of EC and OC, about $10 \%$ due to EC, and $11 \%$ due to OC or OC/dust mixture. For southern California, during the summer/autumn season almost $40 \%$ of the aerosol contribution corresponds to a mixture of EC and $\mathrm{OC}, 27 \%$ corresponds to $\mathrm{OC}$ or OC/dust types and $5 \%$ corresponds to EC. The winter/spring season is dominated by dust (over $45 \%$ ) and coated large particles (almost $30 \%$ ) and no EC type is present.

The EC/OC mixture type seems to dominate in the Ångström matrix classification and indicates the difficulty of separating the sources from column integrated measurements. More fossil fuel sources (primary and secondary) were expected in southern California since it is a more populated, urban area and, in our particular case, the AERONET data are biased by the Los Angeles basin sites. The chemical composition detected during the aircraft campaigns for southern California (Fig. 5a) shows about $35 \%$ of aerosol contribution due to primary fossil fuel sources, $47 \%$ due to secondary fossil fuel sources, and about $15 \%$ due to biomass burning sources. Figure 6d shows that the chemistry component of the Angström matrix (the AAE) has a mean value of 1.1 for primary fossil fuel sources, 1.5 for secondary fossil fuel sources and 1.8 for biomass burning. All those sources would fall into the EC/OC mixture type or the OC type, with some overlapping on the different sources, and leaving the EC type misclassified. On the other hand, northern California was expected to have more biomass burning sources with respect to the south because of the less populated and more rural environment (in particular the AERONET data are bias by the Fresno site in the central valley). The aircraft data in northern California (Fig. 5b and c) indicates about $40 \%$ of the contribution due to secondary fossil fuel sources and about $30 \%$ due to biomass burning sources with a small con- tribution due to primary fossil fuel sources (about 7 to $10 \%$ ). Again, the overlapping of the optical properties results in the EC/OC mixture type dominating the classification.

Pure dust is not a significant source except for southern California during winter/spring. This is most likely a misclassification. The dust type measurements were concentrated in the UCLA and MISR-JPL AERONET stations, both in the Los Angeles metropolitan area, and dust is not expected to make such large contributions in urban areas, where fossil fuel sources are expected to dominate. This suggests that those dust cases were instead larger hygroscopic organic carbon particles that had undergone aqueous phase processing. The aerosol species producing strong absorption at short wavelengths and primarily in the coarse mode are most likely humic-like substances (HULIS) species formed by fog or cloud processing. These aerosols have been detected in California in previous studies (e.g. Qin and Prather, 2006; Qin et al., 2012) and represent organic carbon particles, but are larger than $1 \mu \mathrm{m}$ due to their water content, therefore they might have spectral properties similar to dust, i.e. they are large particles and absorb more radiation at shorter wavelengths (AAE > 1) which can fall in the Dust dominant or Dust/EC mixture types in the Angström matrix. On the other hand, the in-situ chemical composition from the aircraft campaigns indicates the larger contribution due to dust from northern California during the winter as compare to the summer (14\% vs. $6 \%$ ). During the CalWater flights, dust particles were detected mainly at higher altitudes in layers, while during CARES flights were focused at much lower altitudes. Long range transported dust crossing the Pacific has been detected during the winter in northern California and it is thought to have an impact on the precipitation in California (Ault et al., 2011; Creamean et al., 2013).

Most of the AERONET stations used in California are coastal (Fig. 1), and the dominance of sea salt could be important. However, Smirnov et al. (2002, 2011) studied optical properties in maritime environment and found that the AOD has a mean value of 0.07 with standard deviation of 0.03 to 0.05 . This means that in a clean maritime environment, dominated by sea salt, the AOD is far below the limit for AERONET Level 2.0 data. Values above the limit (the values included in this study) must be dominated by anthropogenic 
aerosol or dust. The limitation imposed by AERONET for the Level 2.0 data (AOD greater than 0.4) indicates that anthropogenic aerosols or dust are dominating species in the mixture. Since the SAE is an intensive property that gives an idea of the dominant size mode, this must reflect the dominance of the anthropogenic aerosol or the dust. Moreover, we did not observe a significant bias in the spectral optical properties from inland and coastal AERONET sites. Other nonabsorbing species that might be important such as nitrate or sulfate have been found internally mixed with carbonaceous aerosols in other studies in California (e.g. Pratt and Prather, 2009; Cahill et al., 2012) rather than as single nitrate or sulfate particles.

The differences in sources leading to absorption in the varying regions of California, as shown in Fig. 5, could be biased by the objectives of the flights during each of the campaigns. During CalNex, the flights were comprised of mainly low level passes within the boundary layer in the Los Angeles area, very close to the sources of pollution. On the other hand, CARES also had flights with passes over the Sierra foothills (away from urban sources in the Sacramento area), and intercepting plumes from fires if they were present. CalWater focused on clouds and most of the flights were either over the Sierra foothills or over the coastal area.

The overall in-situ AAE agree with the detected chemical composition. By looking at Fig. 6, we can see that the chemical component of the Angström matrix, the AAE, is smaller on average during CalNex than during CARES, consistent with the type of dominant aerosol detected, more primary fossil fuel during CalNex, in contrast with the secondary fossil fuel and biomass that dominate during CARES. The number of samples for CalWater is small, as the flights focused on clouds. Also, Fig. 6d shows that the AAE has a mean value of $1.1 \pm 0.6$ for primary fossil fuel sources, secondary fossil fuel sources can be associated with an $\mathrm{AAE}=1.5 \pm 0.3$, and biomass burning to $\mathrm{AAE}=1.8 \pm 0.4$. These values agree with the results shown by other authors for $\mathrm{BC}, \mathrm{AAE}=1$ (Bergstrom et al., 2002), and OC, AAE > 1, (Kirchstetter et al., 2004) and for secondary aerosols, AAE > 1, (Gyawali et al., 2009; Lack and Cappa, 2010). More dust data are needed to establish good statistics for this source. On the other hand, the size component of the Ångström matrix, the SAE, shows less variability during CalNex than during CARES, but we need to take into account that the SAE is calculated differently. In addition, the data shown are filtered using the AATOFMS, and the different cut size in the different campaigns modify the ability to sample the largest aerosol.

Finally, the application of the Ångström matrix to the insitu aircraft measurements and comparison with the chemical composition of the aerosol (Table 3) shows some of the limitations of the Angström matrix. Particles detected as a primary fossil fuel source, i.e. elemental carbon, were classified mainly as organic carbon or a mixture of organic carbon and elemental carbon or dust. Taking into account that the classification is based on considering that $75 \%$ of the particles detected by the A-ATOFMS are of that type, the optical properties might contain particles from other types, the same way the external mixing of aerosol on a column integrated value like the AOD, or its absorption and scattering components, would yield to a higher AAE value and, therefore misclassifies the EC type (primary fossil fuel source). This reinforces the conclusions extracted from the comparison of the overall chemical composition for the different regions and seasons in California. Particles detected as secondary fossil fuel, i.e. secondary organic aerosols, fall mainly into the dust/EC mix (almost $40 \%$ ) indicating that those were particles with absorption properties similar to organic carbon (AAE > 1), but larger in size, probably due to the internal mix with nonabsorbing aerosols. This could be biased by the size detection limit of the sampling inlets onboard the aircrafts and the A-ATOFMS. Primary biomass burning measurements were limited: 5.7, 2.3 and $0.6 \%$ of the overall particles detected in CalNex, CARES and CalWater respectively (Fig. 5), but when detected as dominant, the Ångström matrix classified them as organic carbon or organic mixed with dust (50\%), or well mix types (the other $50 \%$ ). The amount of data from this source is very limited and more values are necessary for accurate statistics. Secondary biomass burning dominant sources are the ones that the Angström matrix classifies the best, with almost $60 \%$ falling into the organic carbon or organic carbon mixed with dust. Finally, the dust source is only significant during CalWater (14\% of total) but more data is necessary for accurate statistics.

\section{Conclusions}

Numerous studies have estimated aerosol chemical composition from spectral optical measurements using ground remote sensing measurements, e.g. AERONET or satellites. These networks or satellite platforms provide optical properties on a global scale, which are needed for the assessment of the contribution of aerosols to the radiative forcing and climate. Including information on the chemical composition of aerosols from discrete cases, specifically the absorbing particles sources, can help to identify the sources that contribute to the forcing globally.

In this study, we present a methodology for the estimation of absorbing aerosols speciation from spectral optical measurements, and explored its limitations using in-situ optical measurements and chemical composition. Our estimates are based on the division of the Absorption Ångström Exponent vs. Scattering Ångström Exponent space and it is applied to ten AERONET stations in California. In order to validate this approach, in-situ optical properties from three aircraft campaigns that took place in California between 2010 and 2011 with single particle chemical composition measurements were analyzed. To explore the range of sources, the AERONET data and in-situ aircraft data were divided into 
regions (northern and southern California) and seasons (winter/spring and summer/autumn).

In-situ chemical composition results reveal a higher contribution from fossil fuel sources in southern California in contrast with more biomass burning sources in northern California. The estimation of aerosol types with spectral optical properties shows a dominance of mixed types. Pure EC is underestimated since it is being classified as a mixture of EC and OC. This is expected from column integrated aerosol optical properties, and the overlapping of sources and optical properties is also revealed in the in-situ measurements. Also, non-absorbing species internally mixed with carbonaceous species might lead to mixture types towards larger sizes. Comparison of detailed chemical measurements and spectral properties reveals that secondary organic aerosols processed in aqueous phase might be a significant contributor in urban areas with a predominance of smog events, such as the Los Angeles basin.

On the other hand, applying the technique to estimate the chemical composition with spectral optical measurements, the Ångström matrix, to in-situ optical measurements including the actual chemical composition also show the limitations in the optical separation of the sources. Primary sources are difficult to classify, since the column integrated measurements result in particles being classified as a mixture. Secondary species are well classified, but the separation between fossil fuel and biomass burning sources has limitations because of the overlapping of the optical properties. In general, $\mathrm{OC}$ is better identified as a biomass burning source than a secondary fossil fuel source.

In conclusion, the availability of long-term global optical properties provides an opportunity for longer term estimates of aerosol types over a larger spatial scale. However, co-located studies for some overlapping period of time with actual chemical composition measurements are necessary in order to constrain the applicability of the technique to specific regions. This will be necessary if we want to develop this tool into a general approach for accurately addressing the contribution of different aerosol sources to regional and global radiative forcing.

Acknowledgements. Funding for this work was provided by CARB under agreement no. 08-323. The statements and conclusions in this report are those of the researchers and not necessarily those of the California Air Resources Board. The mention of any commercial products, their source, or their use in connection with the material reported is not construed as actual or implied endorsement of such products.

We would like to thank the field staff involved in the deployment of the G1 during CARES and CalWater. The deployment of the G-1 was funded by the Atmospheric Radiation Measurement (ARM) Program sponsored by the US Department of Energy (DOE), Office of Biological and Environmental Research (OBER) and the US DOE's Atmospheric System Research (ASR) Program under Contract DE-AC06-76RLO 1830 at PNNL for CARES, and by the
California Energy Commission under contract CEC 500-09-043 and 500-09-032 for CalWater. The deployment of the Twin Otter during CalNex was supported by NOAA grant NA090AR4310128. We also would like to thank the people involved during the CalNex campaign, and especially to Haflidi Jonsson who provided useful insight with the optical measurement from the Twin Otter.

We also would like to thank all the PI investigators and their staff for establishing and maintaining the AERONET sites used in this investigation.

Edited by: X. Querol

\section{References}

Anderson, T. L. and Ogren, J. A.: Determining aerosol radiative properties using the TSI-3563 integrating nephelometer, Aerosol Sci. Technol., 29, 57-69, 1998.

Andreae, M. O. and Gelencsér, A.: Black carbon or brown carbon? The nature of light-absorbing carbonaceous aerosols, Atmos. Chem. Phys., 6, 3131-3148, doi:10.5194/acp-6-3131-2006, 2006.

Ault, A. P., Williams, C. R., White, A. B., Neiman, P. J., Creamean, J. M., Gaston, C. J., Ralph, F. M., and Prather, K. A.: Detection of Asian dust in California orographic precipitation, J. Geophys. Res., 116, 1-15, 2011.

Bahadur, R., Praveen, P. S., Xu, Y. Y., and Ramanathan, V.: Solar absorption by elemental carbon and brown carbon determined from spectral observations, P. Natl. Acad. Sci. USA., 109, 1736617371, 2012.

Bahreini, R., Jimenez, J. L., Wang, J., Flagan, R. C., Seinfeld, J. H., Jayne, J. T., and Worsnop, D. R.: Aircraft-based aerosol size and composition measurements during ACE-Asia using an Aerodyne aerosol mass spectrometer, J. Geophys. Res., 108, 8645, doi:10.1029/2002JD003226, 2003.

Barnaba, F. and Gobbi, G. P.: Aerosol seasonal variability over the Mediterranean region and relative impact of maritime, continental and Saharan dust particles over the basin from MODIS data in the year 2001, Atmos. Chem. Phys., 4, 2367-2391, doi:10.5194/acp-4-2367-2004, 2004.

Bergstrom, R. W., Russell, P. B., and Hignett, P.: Wavelength dependence of the absorption of black carbon particles: Predictions and results from the TARFOX experiment and implications for the aerosol single scattering albedo, J. Atmos. Sci., 59, 567-577, 2002.

Bergstrom, R. W., Pilewskie, P., Russell, P. B., Redemann, J., Bond, T. C., Quinn, P. K., and Sierau, B.: Spectral absorption properties of atmospheric aerosols, Atmos. Chem. Phys., 7, 5937-5943, doi:10.5194/acp-7-5937-2007, 2007.

Bond, T. C. and Bergstrom, R. W.: Light Absorption by Carbonaceous Particles: An Investigative Review, Aerosol. Sci. Technol., 40, 27-67, 2006.

Bond, T. C., Anderson, T. L., and Campbell, D.: Calibration and intercomparison of filter-based measurements of visible light absorption by aerosols, Aerosol Sci. Technol., 30, 582-600, 1999.

Cahill, J. F., Suski, K., Seinfeld, J. H., Zaveri, R. A., and Prather, K. A.: The mixing state of carbonaceous aerosol particles in northern and southern California measured during CARES and CalNex 2010, Atmos. Chem. Phys., 12, 10989-11002, doi:10.5194/acp-12-10989-2012, 2012. 
Chow, J. C., Watson, J. G., Doraiswamy, P., Chen, L. W. A., Sodeman, D. A., Lowenthal, D. H., Park, K., Arnott, W. P., and Motallebi, N.: Aerosol light absorption, black carbon, and elemental carbon at the Fresno Supersite, California, Atmos. Res., 93, 874887, 2009.

Collaud Coen, M., Weingartner, E., Schaub, D., Hueglin, C., Corrigan, C., Henning, S., Schwikowski, M., and Baltensperger, U.: Saharan dust events at the Jungfraujoch: detection by wavelength dependence of the single scattering albedo and first climatology analysis, Atmos. Chem. Phys., 4, 2465-2480, doi:10.5194/acp4-2465-2004, 2004.

Creamean, J. M., Suski, K. J., Rosenfeld, D., Cazorla, A., DeMott, P. J., Sullivan, R. C., White, A. B., Ralph, F. M., Minnis, P., Comstock, J. M., Tomlinson, J. M., and Prather, K. A.: Dust and biological aerosols from the Sahara and Asia influence precipitation in the Western U.S., Science, 340, 1572-1578, 2013.

Dubovik, O. and King, M. D.: A flexible inversion algorithm for retrieval of aerosol optical properties from Sun and sky radiance measurements, J. Geophys. Res., 105, 20673-20696, 2000.

Dubovik, O., Holben, B. N., Eck, T. F., Smirnov, A., Kaufman, Y. J., King, M. D., Tanré, D., and Slutsker, I.: Variability of absorption and optical properties of key aerosol types observed in worldwide locations, J. Atmos. Sci., 59, 590-608, 2002.

Eck, T. F., Holben, B. N., Reid, J. S., Dubovik, O., Smirnov, A., O'Neill, N. T., Slutsker, I., and Kinne, S.: Wavelength dependence of the optical depth of biomass burning, urban, and desert dust aerosols, J. Geophys. Res., 104, 31333-31349, 1999.

Fialho, P., Hansen, A. D. A., and Honrath, R. E.: Absorption coefficients by aerosols in remote areas: A new approach to decouple dust and black carbon absorption coefficients using sevenwavelength Aethalometer data, J. Aerosol Sci., 36, 267-282, 2005.

Forster, P., Ramaswamy, V., Artaxo, P., Berntsen, T., Betts, R., Fahey, D.W., Haywood, J., Lean, J., Lowe, D. C., Myhre, G., Nganga, J., Prinn, R., Raga, G., Schulz, M., and Van Dorland, R.: Changes in Atmospheric Constituents and in Radiative Forcing, in: Climate Change 2007: The Physical Science Basis, Contribution of Working Group I to the Fourth Assessment Report of the Intergovernmental Panel on Climate Change, edited by: Solomon, S., Qin, D., Manning, M., Chen, Z., Marquis, M., Averyt, K. B., Tignor, M., and Miller, H. L., Cambridge University Press, Cambridge, United Kingdom and New York, NY, USA, 2007.

Giles, D. M., Holben, B. N., Tripathi, S. N., Eck, T. F., Newcomb, W. W., Slutsker, I., Dickerson, R. R., Thompson, A. M., Mattoo, S., Wang, S.-H., Singh, R. P., Sinyuk, A., and Schafer, J. S.: Aerosol properties over the Indo Gangetic Plain: A mesoscale perspective from the TIGERZ experiment, J. Geophys. Res., 116, D18203, doi:10.1029/2011JD015809, 2011.

Giles, D. M., Holben, B. N., Eck, T. F., Sinyuk, A., Smirnov, A., Slutsker, I., Dickerson, R. R., Thompson, A. M., and Schafer, J. S.: An analysis of AERONET aerosol absorption properties and classifications representative of aerosol source regions, J. Geophys. Res., 117, D17203, doi:10.1029/2012JD018127, 2012.

Gyawali, M., Arnott, W. P., Lewis, K., and Moosmüller, H.: In situ aerosol optics in Reno, NV, USA during and after the summer 2008 California wildfires and the influence of absorbing and non-absorbing organic coatings on spectral light absorption, Atmos. Chem. Phys., 9, 8007-8015, doi:10.5194/acp-9-8007-2009, 2009.
Haywood, J. M. and Shine, K. P.: The effect of anthropogenic sulfate and soot aerosol on the clear sky planetary radiation budget, Geophys. Res. Lett., 22, 603-606, 1995.

Hegg, D. A., Covert, D. S., Jonsson, H., and Covert, P. A.: Determination of the transmission efficiency of an aircraft aerosol inlet, Aerosol Sci. Technol., 39, 966-971, 2005.

Higurashi, A. and Nakajima, T.: Detection of aerosol types over the East China Sea near Japan from four-channel satellite data, Geophys. Res. Lett., 29, 1836, doi:10.1029/2002GL015357, 2002.

Hoffer, A., Gelencsér, A., Guyon, P., Kiss, G., Schmid, O., Frank, G. P., Artaxo, P., and Andreae, M. O.: Optical properties of humic-like substances (HULIS) in biomass-burning aerosols, Atmos. Chem. Phys., 6, 3563-3570, doi:10.5194/acp-6-3563-2006, 2006.

Holben, B. N., Eck, T. F., Slutsker, I., Tanré, D., Buis, J. P., Setzer, A., Vermote, E., Reagan, J. A., Kaufman, Y. J., Nakajima, T., Lavenu, F., Jankowiak, I., and Smirnov, A.: AERONET-A federated instrument network and data archive for aerosol characterization, Remote Sens. Environ., 66, 1-16, 1998.

Hudson, P. K., Murphy, D. M., Cziczo, D. J., Thomson, D. S., de Gouw, J. A., Warneke, C., Holloway, J., Jost, J. R., and Hubler, G.: Biomass-burning particle measurements: Characteristic composition and chemical processing, J. Geophys. Res., 109, D23S27, doi:10.1029/2003JD004398, 2004.

Jacobson, M. Z.: Isolating nitrated and aromatic aerosols and nitrated aromatic gases as sources of ultraviolet light absorption, J. Gephys. Res., 104, 3527-3542, 1999.

Jacobson, M. C., Hansson, H. C., Noone, K. J., and Charlson, R. J.: Organic Atmospheric Aerosols: Review and State of the Science, Rev. Geophys., 38, 267-294, 2000.

Jeong, M. J. and Li, Z.: Quality, compatibility, and synergy analyses of global aerosol products derived from the advanced very high resolution radiometer and total ozone mapping spectrometer, J. Geophys. Res., 110, D10S08, doi:10.1029/2004JD004647, 2005.

Kalapureddy, M. C. R., Kaskaoutis, D. G., Ernest Raj, P., Devara, P. C. S., Kambezidis, H. D., Kosmopoulos, P. G., and Nastos, P. T.: Identification of aerosol type over the Arabian Sea in the premonsoon season during the Integrated Campaign for Aerosols, Gases and Radiation Budget (ICARB), J. Geophys. Res., 114, D17203, doi:10.1029/2009JD011826, 2009.

Kaskaoutis, D. G., Kosmopoulos, P., Kambezidis, H. D., and Nastos, P. T.: Aerosol climatology and discrimination of different types over Athens, Greece based on MODIS data, Atmos. Environ., 41, 7315-7329, 2007.

Kaufman, Y. J., Boucher, O., Tanré, D., Chin, M., Remer, L. A., and Takemura, T.: Aerosol anthropogenic component estimated from satellite data, Geophys. Res. Lett., 32, L17804, doi:10.1029/2005GL023125, 2005.

Kim, J., Lee, J., Lee, H. C., Higurashi, A., Takemura, T., and Song, C. H.: Consistency of the aerosol type classification from satellite remote sensing during the atmospheric brown cloud-East Asia regional experiment campaign, J. Geophys. Res., 112, D22S33, doi:10.1029/2006JD008201, 2007.

Kirchstetter, T. W., Novakov, T., and Hobbs, P. V.: Evidence that the spectral dependence of light absorption by aerosols is affected by organic carbon, J. Goephys. Res., 109, D21208, doi:10.1029/2004JD004999, 2004.

Koch, D., Bond, T. C., Streets, D., Unger, N., and van der Werf, G. R.: Global impacts of aerosols from particular 
source regions and sectors, J. Geophys. Res., 112, D02205, doi:10.1029/2005JD007024, 2007.

Lack, D. A. and Cappa, C. D.: Impact of brown and clear carbon on light absorption enhancement, single scatter albedo and absorption wavelength dependence of black carbon, Atmos. Chem. Phys., 10, 4207-4220, doi:10.5194/acp-10-4207-2010, 2010.

Magi, B. I., Ginoux, P., Ming, Y., and Ramaswamy, V.: Evaluation of tropical and extratropical Southern Hemisphere African aerosol properties simulated by a climate model, J. Geophys. Res., 114, D14204, doi:10.1029/2008JD011128, 2009.

Meloni, D., di Sarra, A., Pace, G., and Monteleone, F.: Aerosol optical properties at Lampedusa (Central Mediterranean). 2. Determination of single scattering albedo at two wavelengths for different aerosol types, Atmos. Chem. Phys., 6, 715-727, doi:10.5194/acp-6-715-2006, 2006.

Mielonen, T., Arola, A., Komppula, M., Kukkonen, J., Koskinen, J., de Leeuw, G., and Lehtinen, K. E. J.: Comparison of CALIOP level 2 aerosol subtypes to aerosol types derived from AERONET inversion data, Geophys. Res. Lett., 36, L18804, doi:10.1029/2009GL039609, 2009.

Moffet, R. C. and Prather, K. A.: In situ measurements of the mixing state and optical properties of soot: Implications for radiative forcing estimates, P. Natl. Acad. Sci. USA, 106, 11872-11877, 2009.

Myhre, G., Hoyle, C. R., Berglen, T. F., Johnson, B. T., and Haywood, J. M.: Modeling of the solar radiative impact of biomass burning aerosols during the Dust and Biomassburning Experiment (DABEX), J. Geophys. Res., 113, D00C16, doi:10.1029/2008JD009857, 2008.

Ogren, J. A.: Comment on "Calibration and Intercomparison of Filter-Based Measurements of Visible Light Absorption by Aerosols", Aerosol Sci. Technol., 44, 589-591, 2010.

Pratt, K. A. and Prather, K. A.: Real-Time, Single-Particle Volatility, Size, and Chemical Composition Measurements of Aged Urban Aerosols, Environ. Sci. Technol., 43, 8276-8282, 2009.

Pratt, K. A., Mayer, J. E., Holecek, J. C., Moffet, R. C., Sanchez, R. O., Rebotier, T. P., Furutani, H., Gonin, M., Fuhrer, K., Su, Y., Guazzotti, S., and Prather, K.: Development and characterization of an aircraft aerosol time-of-flight mass spectrometer, Anal. Chem., 81, 1792-1800, 2009.

Qin, X. and Prather, K.: Impact of biomass emissions on particle chemistry during the California Regional Particulate Air Quality Study, Int. J. Mass Spectrom., 258, 142-150, 2006.

Qin, X., Pratt, K. A., Shields, L. G., Toner, S. M., and Prather, K. A.: Seasonal Comparisons of Single-Particle Chemical Mixing State in Riverside, CA, Atmos. Environ., 59, 587-596, doi:10.1016/j.atmosenv.2012.05.032, 2012

Ramanathan, V. and Carmichael, G.: Global and Regional Climate Changes Due to Black Carbon, Nat. Geosci., 1, 221-227, 2008.

Russell, P. B., Bergstrom, R. W., Shinozuka, Y., Clarke, A. D., DeCarlo, P. F., Jimenez, J. L., Livingston, J. M., Redemann, J., Dubovik, O., and Strawa, A.: Absorption Angstrom Exponent in AERONET and related data as an indicator of aerosol composition, Atmos. Chem. Phys., 10, 1155-1169, doi:10.5194/acp-101155-2010, 2010.

Schmid, B., Ferrare, R., Flynn, C., Elleman, R., Covert, D., Strawa, A., Welton, E., Turner, D., Jonsson, H., Redemann, J., Eilers, J., Ricci, K., Hallar, A. G., Clayton, M., Michalsky, J., Smirnov, A., Holben, B., and Barnard, J.: How well do state-of- the-art techniques measuring the vertical profile of tropospheric aerosol extinction compare?, J. Geophys. Res., 111, D05S07, doi:10.1029/2005JD005837, 2006.

Schnaiter, M., Linke, C., Mohler, O., Naumann, K. H., Saathoff, H., Wagner, R., Schurath, U., and Wehner, B.: Absorption Amplification of Black Carbon Internally Mixed with Secondary Organic Aerosol, J. Geophys. Res.-Atmos., 110, D19204, doi:10.1029/2005JD006046, 2005.

Schuster, G. L., Dubovik, O., and Holben, B. N.: Ångstrom exponent and bimodal aerosol size distributions, J. Geophys. Res., 111, D07207, doi:10.1029/2005JD006328, 2006.

Silva, P. J. and Prather, K. A.: Interpretation of mass spectra from organic compounds in aerosol time-of-flight mass spectrometry, Anal. Chem., 72, 3553-3562, 2000.

Silva, P. J., Liu, D. Y., Noble, C. A., and Prather, K. A.: Size and chemical characterization of individual particles resulting from biomass burning of local Southern California species, Environ. Sci. Technol., 33, 3068-3076, 1999.

Silva, P. J., Carlin, R. A., and Prather, K. A.: Single particle analysis of suspended soil dust from Southern California, Atmos. Environ., 34, 1811-1820, 2000.

Smirnov, A., Holben, B. N., Kaufman, Y. J., Dubovik, O., Eck, T. F., Slutsker, I., Pietras, C., and Halthore, R. N.: Optical Properties of Atmospheric Aerosol in Maritime Environments, J. Atmos. Sci., 59, 501-523, 2002.

Smirnov, A., Holben, B. N., Giles, D. M., Slutsker, I., O’Neill, N. T., Eck, T. F., Macke, A., Croot, P., Courcoux, Y., Sakerin, S. M., Smyth, T. J., Zielinski, T., Zibordi, G., Goes, J. I., Harvey, M. J., Quinn, P. K., Nelson, N. B., Radionov, V. F., Duarte, C. M., Losno, R., Sciare, J., Voss, K. J., Kinne, S., Nalli, N. R., Joseph, E., Krishna Moorthy, K., Covert, D. S., Gulev, S. K., Milinevsky, G., Larouche, P., Belanger, S., Horne, E., Chin, M., Remer, L. A., Kahn, R. A., Reid, J. S., Schulz, M., Heald, C. L., Zhang, J., Lapina, K., Kleidman, R. G., Griesfeller, J., Gaitley, B. J., Tan, Q., and Diehl, T. L.: Maritime aerosol network as a component of AERONET - first results and comparison with global aerosol models and satellite retrievals, Atmos. Meas. Tech., 4, 583-597, doi:10.5194/amt-4-583-2011, 2011.

Song, X. H., Hopke, P. K., Fergenson, D. P. and Prather, K. A.: Classification of single particles analyzed by ATOFMS using an artificial neural network, ART-2A, Anal. Chem., 71, 860-865, 1999.

Spencer, M. T. and Prather, K. A.: Using ATOFMS to determine OC/EC mass fractions in particles, Aerosol Sci. Technol., 40, 585-594, 2006.

Torres, O., Bhartia, P. K., Syniuk, A., Welton, E., and Holben, B.: Total Ozone Mapping Spectrometer measurements of aerosol absorption from space: Comparison to SAFARI 2000 ground-based observations, J. Geophys. Res., 110, D10S18, doi:10.1029/JD004611, 2005.

Yu, H., Chin, M., Remer, L. A., Kleidman, R. G., Bellouin, N., Bian, H., and Diehl, T.: Variability of marine aerosol finemode fraction and estimates of anthropogenic aerosol component over cloud-free oceans from the Moderate Resolution Imaging Spectroradiometer (MODIS), J. Geophys. Res., 114, D10206, doi:10.1029/2008JD010648, 2009.

Zaveri, R. A., Shaw, W. J., Cziczo, D. J., Schmid, B., Ferrare, R. A., Alexander, M. L., Alexandrov, M., Alvarez, R. J., Arnott, W. P., Atkinson, D. B., Baidar, S., Banta, R. M., Barnard, J. C., Be- 
ranek, J., Berg, L. K., Brechtel, F., Brewer, W. A., Cahill, J. F., Cairns, B., Cappa, C. D., Chand, D., China, S., Comstock, J. M., Dubey, M. K., Easter, R. C., Erickson, M. H., Fast, J. D., Floerchinger, C., Flowers, B. A., Fortner, E., Gaffney, J. S., Gilles, M. K., Gorkowski, K., Gustafson, W. I., Gyawali, M., Hair, J., Hardesty, R. M., Harworth, J. W., Herndon, S., Hiranuma, N., Hostetler, C., Hubbe, J. M., Jayne, J. T., Jeong, H., Jobson, B. T., Kassianov, E. I., Kleinman, L. I., Kluzek, C., Knighton, B., Kolesar, K. R., Kuang, C., Kubátová, A., Langford, A. O., Laskin, A., Laulainen, N., Marchbanks, R. D., Mazzoleni, C., Mei, F., Moffet, R. C., Nelson, D., Obland, M. D., Oetjen, H., Onasch,
T. B., Ortega, I., Ottaviani, M., Pekour, M., Prather, K. A., Radney, J. G., Rogers, R. R., Sandberg, S. P., Sedlacek, A., Senff, C. J., Senum, G., Setyan, A., Shilling, J. E., Shrivastava, M., Song, C., Springston, S. R., Subramanian, R., Suski, K., Tomlinson, J., Volkamer, R., Wallace, H. W., Wang, J., Weickmann, A. M., Worsnop, D. R., Yu, X.-Y., Zelenyuk, A., and Zhang, Q.: Overview of the 2010 Carbonaceous Aerosols and Radiative Effects Study (CARES), Atmos. Chem. Phys., 12, 7647-7687, doi:10.5194/acp-12-7647-2012, 2012. 